\title{
LA CURACIÓN AL FILO DE UNA NAVAJA Proyecciones DEL JUICIO EN LE SPLEEN DE PARIS
}

\author{
Magdalena Cámpora \\ Universidad Católica Argentina \\ Consejo Nacional de Investigaciones Científicas y Técnicas \\ magdalacampora@gmail.com
}

Resumen: En diálogo con un trabajo previo donde estudiamos la incidencia del régimen editorial, mediático y jurídico posterior a 1830 en la constitución de Les Fleurs du mal, en este artículo buscamos analizar los efectos del juicio y la censura de 1857 en dos textos del Spleen de Paris, "A Arsène Houssaye" (1862) y "Mademoiselle Bistouri” (1867).

Palabras clave: Baudelaire, Mademoiselle Bistouri, Censura, Serpiente, Composición.

\begin{abstract}
In dialogue with a previous work where we studied the incidence of the editorial, media and legal regime post 1830 in the constitution of Les Fleurs $d u$ mal, this article examines the effects of the trial and censorship of 1857 in two texts of the Spleen de Paris, "A Arsène Houssaye" (1862) and "Mademoiselle Bistouri" (1867).
\end{abstract}

Keywords: Baudelaire, Mademoiselle Bistouri, Censorship, Serpent, Composition. 
Puisque j'ai prononcé ce mot splendide et terrible, la Justice...

Baudelaire, "Madame Bovary par Gustave Flaubert"

La carta-prefacio a Arsène Houssaye y "Mademoiselle Bistouri" suscitan desde hace algunos años una atención crítica particular. Esa popularidad resulta, según Elissa Marder (2017, p. 14), de la notable productividad de sus temáticas para la agenda teórica actual: ambivalencia genérica y fetichismo de la imagen fotográfica (Murphy, 2003, pp. 497-509; Thélot, 2014; Marder, 2017; Foerster, 2018, pp. 175-186); monstruosidad y mirada clínica (Linton, 2014); recapitulación autorreflexiva e irónica de la obra previa (Cornille, 2010, p. 103; Marder, 2017, pp.18-19); experiencia de la lectura aleatoria y autonomía del fragmento (Zanelli Quarantini, 2008, p.185; Hannoosh, 2011, p. 387). Quisiéramos aquí, por nuestra parte, asumir destempladamente una perspectiva histórica, y examinar cómo los efectos del juicio de 1857 siguen trabajando -cinco, siete, diez años más tarde- el proyecto de estructuración y la poética de los Petits Poèmes en prose, que atraviesa la inquietante figura de Mademoiselle Bistouri. Esta perspectiva se encuentra en diálogo con un trabajo previo en el que analizábamos la incidencia del régimen editorial, mediático y jurídico posterior a 1830 en la constitución textual de Les Fleurs du mal (Cámpora, 2019). Allí se buscaba estudiar la relación entre la "delación" " mediática y la violencia penal a la que se sometió la obra, en

\footnotetext{
${ }^{1}$ La expresión que usa Baudelaire es "dénonciation" y se refiere al artículo de Gustave Bourdin publicado en Le Figaro el 5 de julio de 1857 (Charles Baudelaire, Euvres Complètes I, París, Gallimard, 1975, p. 1177).
} 
1857, con las posteriores alteraciones en la estructura y los soportes editoriales del texto.

Se trata, ahora, de seguir el hilo de esa trama en el Spleen de Paris, y de analizar hasta dónde las imágenes nucleares de la escisión y del recorte pueden ser leídas como elaboraciones estéticas y paródicas de los episodios ligados al juicio y la censura de 1857. Leer el Spleen de Paris desde el acuciante deseo de reparación y venganza de la condena penal: el enfoque se desprende, como veremos, de las propias instrucciones de lectura que Baudelaire disemina en su correspondencia, donde asocia estructuralmente la primera versión del poemario con los poemas en prosa. De forma temprana, Claude Pichois ya había señalado al juicio de 1857 como el lazo subterráneo que unía el proyecto de las Flores con el del Spleen de Paris. Recientes trabajos baudelairianos profundizan esta línea: Michelle Hannoosh (2011, p. 387) proyecta en toda la poética del Spleen el modelo de lectura impuesto por el juicio; para Franca Zanelli (2008, p.180), la carta a Houssaye se encuentra "atravesada" por la metáfora de la amputación, que Baudelaire utiliza en los tiempos del juicio para describir los efectos de la censura; JeanLouis Cornille (2010, p. 103) releva vestigios factuales del proceso penal en el poema en prosa de la Bistouri. Quisiéramos, por nuestra parte, extremar la perspectiva y entender estas "tortuosas fantasías" en el sentido que Laplanche y Pontalis dan al término: la fantasía como "guion imaginario en el que se halla presente el sujeto y que representa, en forma más o menos deformada por los procesos defensivos, la realización de un deseo" (1967, p. 138). De particular interés nos resultan los campos semánticos de la 
escisión y el recorte, presentes en la dedicatoria a Arsène Houssaye de 1862 y en "Mademoiselle Bistouri" de 1867. Escisión y recorte: esos procesos por un lado remiten, en nuestra lectura, al acto específico de la supresión (vivida por Baudelaire como una mutilación ${ }^{2}$ ) de los seis poemas censurados, y por el otro aluden a aquellos personajes alegóricos de la censura que, desde la Restauración ${ }^{3}$, los caricaturistas representan con tijeras, navajas y otros elementos cortantes: Dame Censure, Dame Séraphine, Dame aux ciseaux, Anastasie (Delporte 1997).

Este trabajo por lo demás responde a una necesidad práctica, austral, surgida de la tarea como docente universitaria: no parece haber en castellano una bibliografía que ordene y problematice el conjunto de estos temas, centrales para el estudio de un poeta cuya primera recepción latinoamericana a fines del XIX y principios del XX se encuentra fuertemente mediada por la mitografía del maldito. Es ésta también entonces una lectura hecha desde los enredos, el papeleo y el "desorden bufón de las repúblicas de América del Sur" (OC I, p. 665) que el último Baudelaire tanto temía -o ansiaba- para la civilización de Occidente apremiada por la "atrofia espiritual" del progreso. ${ }^{4}$

\footnotetext{
${ }^{2}$ El término aparece tanto en la correspondencia como en los proyectos de prefacio.

${ }^{3}$ Las leyes de censura en contra de "crímenes o delitos por vía de prensa o de cualquier otro medio de publicación” datan de marzo 1820.

4 «Je ne dis pas que le monde sera réduit aux expédients et au désordre bouffon des républiques du Sud-Amérique, que peut-être même nous retournerons à l'état sauvage, et que nous irons, à travers les ruines herbues de notre civilisation, chercher notre pâture, un fusil à la main. Non ; car ces aventures supposeraient encore une certaine énergie vitale, écho des premiers âges. » (OC I, p. 665).
} 


\section{La estructura en díptico}

De forma reiterada en su correspondencia, entre 1863 y 1866, Baudelaire define los poemas en prosa que constituirán Le Spleen de Paris como un "pendant" -la contraparte, el contrapeso- de Les Fleurs du mal. A Victor Hugo, en diciembre de 1863: "Pienso enviarle muy pronto Les Fleurs du mal (nuevamente aumentadas) junto al Spleen de Paris, que será su contraparte $^{5}$ " (Corr II, p. 339). A Sainte-Beuve, en mayo de 1865: "Siempre me impongo tareas difíciles. Hacer cien laboriosas bagatelas (...) tengo unas sesenta, y no puedo seguir más" (Corr II, p. 493). ${ }^{6}$ Cien poemas en prosa -el Spleen tal como lo conocemos tendrá finalmente cincuenta- que funcionarán en díptico con los cien poemas iniciales de la edición de 1857. La relación estructural y especular entre ambas obras vuelve con insistencia en los proyectos de publicación expuestos en las cartas a agentes, amigos, eventuales editores: "1 ${ }^{\circ}$ Fleurs du mal. $2^{\circ}$ Spleen de Paris, que le sirve de contrapeso" (agosto 1865, Corr II, p. 523); "El Spleen de Paris, para hacer de contrapeso a las Fleurs du mal (en prosa)" (febrero 1866, Corr II, p. 591). ${ }^{7}$ Sabemos que Baudelaire no tendrá nunca entre sus manos el Spleen de Paris, editado póstumamente por Asselineau y Banville en el tomo IV de las

\footnotetext{
5 «Je me propose de vous envoyer prochainement Les Fleurs du Mal (encore augmentées) avec Le Spleen de Paris, destiné à leur servir de pendant. »

${ }^{6}$ "Je me mets toujours sur les bras des besognes difficiles. Faire cent bagatelles laborieuses (...) je n'en suis qu'à soixante, et je ne peux plus aller. »

7 Ver también las otras ocurrencias del motivo del "pendant", enumeradas por Pichois: Corr II, p. 512, p. 566, p. 572, p. 591.
} 
Cuvres Complètes de 1869. Los fieles amigos siguieron un índice manuscrito por el poeta, quizá redactado en Bruselas, donde se establecía el ordenamiento futuro de los textos (OC I, 1975, p. 1306). De esos cincuenta poemas, veinte fueron publicados en el sócalo del diario La Presse que dirigía Arsène Houssaye, en tres entregas: 26 y 27 de agosto, 24 de septiembre de 1862.

La simetría numérica era una de las marcas formales que ligaban al Spleen con Las Flores: según Pichois, una "oposición complementaria" (OC I, p. 1300) ensambla los textos; asimismo, para Alain Vaillant el propósito enunciado en la carta a Houssaye funciona como el "negativo" del férreo plan de composición de las Flores (2007, p. 272). Recordemos que la primera edición de Les Fleurs du mal responde a una estructura precisamente calibrada, pensada en contra del "sistema de fragmentación de los diarios" que el poeta describe en sus cartas (Corr II, p. 256). Alain Vaillant, en su Baudelaire, poète comique (2007, pp. 255-290), ha demostrado con eficacia cómo la cohesión de la edición de 1857 se sostiene en una "lógica de la concatenación" que juega con efectos sutiles de simetría tales como la duplicación de motivos, el desplazamiento irónico del mismo motivo en un nuevo escenario, el anuncio de una imagen que luego se amplía en el poema subsiguiente, la reinterpretación antifrástica del mismo tema en dos poemas, los efectos de anadiplosis, los encadenamientos narrativos entre textos. Las junturas son locales y generan racimos de poemas que aseguran la cohesión del cuerpo textual, en un 
proyecto de estructuración formal premeditado y significante . $^{8}$ Esto explicaría la posterior insistencia de Baudelaire, en el momento del juicio, sobre la necesidad de evaluar el libro como un todo: "el libro debe ser juzgado en su conjunto, sólo entonces aparece su terrible moralidad" (OC I, p. 193); "varios textos no incriminados refutan los poemas incriminados. Un libro de poesía debe ser apreciado como conjunto y en función de su conclusión" (ibid.). ${ }^{10}$ En el mismo sentido va el argumento de Barbey d'Aurévilly -tal vez pergeñado junto a Baudelaire- de la "arquitectura secreta" del poemario. ${ }^{11}$

Tras el juicio, uno de los considerandos del veredicto exige la supresión de seis poemas; ese corte desbarata por completo la estructura cuidadosamente elaborada por el poeta. La gravedad simbólica de la condena penal se potencia si seguimos la hipótesis de Michel Butor (1961, p. 37-39) para quien el estatuto de "poeta publicado" había logrado lavar, o

8 Esa tersa estructura formal habilita y sostiene, de hecho, las posteriores interpretaciones temáticas del poemario que hará la crítica. Ver por ejemplo Ruff, 1955; Milner, 1967, pp. 112-113; Leakey, 1991, pp. 577-581.

${ }^{9}$ "Le livre doit être jugé dans son ensemble, et alors il en ressort une terrible moralité. »

10 «Plusieurs morceaux non incriminés réfutent les poèmes incriminés. Un livre de poésie doit être apprécié dans son ensemble et par sa conclusion.»

${ }^{11}$ El artículo de Barbey aparece en Le Pays el 24 de julio 1857, una semana antes de la audiencia, para evitar el ensañamiento con algunos poemas considerados particularmente culpables. Escribe : «(...) dans le livre de M. Baudelaire, chaque poésie a (...) une valeur très-importante d'ensemble et de situation qu'il ne faut pas lui faire perdre, en la détachant. Les artistes qui voient les lignes sous le luxe et l'efflorescence de la couleur percevront très bien qu'il y a ici une architecture secrète, un plan calculé par le poète, méditatif et volontaire. Les Fleurs du mal ne sont pas à la suite les unes des autres comme tant de morceaux lyriques, dispersés par l'inspiration, et ramassés dans un recueil sans d'autre raison que de les réunir. Elles sont moins des poésies qu'une œuvre poétique de la plus forte unité. » (Guyaux, 2007, p.197) 
por lo menos aplacar, la antigua ofensa del consejo de tutela. Butor sostiene que la reparación de esa humillación inicial empieza incluso antes de la aparición de Las Flores, cuando Baudelaire entrega a la imprenta su primera traducción de Poe, en $1856^{12}$, y se convierte en autor publicado de un libro. La publicación "lo vuelve adulto y libre" (p. 39), escribe Butor, lo que permite por lo demás medir el alto daño simbólico contenido en la coacción jurídica de 1857, que avasalla el proyecto estético al imperativo legal y despoja al poeta de su soberanía como autor. Nuevamente se le retira a Baudelaire el derecho a decidir sobre lo propio: primero la herencia, luego la obra.

A partir de ese momento, las sucesivas ediciones y formatos (libro, plaqueta, suplemento) de Les Fleurs du mal presentarán proyectos varios de amplificación, dilatación o achicamiento de la estructura. Como si el poeta buscara, una y otra vez, recuperar la autoridad final sobre el contenido del libro, ahogando la inicial coacción jurídica con nuevos poemas, nuevas secciones en la estructura, nuevos soportes materiales. A la edición de 1857 le siguen la segunda edición de 1861; Le Parnasse satyrique que reproduce los textos condenadas en 1864; Les Épaves y las Nouvelles Fleurs du mal, ambas de 1866. La tercera edición "definitiva" de Las Flores será proyectada desde $1862,{ }^{13}$ pero nunca supervisada por Baudelaire. La elaboración

\footnotetext{
12 Baudelaire firma, el 3 de agosto 1855, su primer contrato con Michel Lévy para Histoires Extraordinaires y Nouvelles Histoires Extraordinaires. Entre 1856 y 1867, Lévy reeditó siete veces $H E$; entre el 56 y el 65, publica cuatro ediciones de NHE, y dos de las Aventures d'Artbur Gordon Pym (1858-1862). En 1863 publica la traducción de Eureka y en 1865, la de las Histoires grotesques et sérieuses.

${ }^{13}$ Ver al respecto la carta a Poulet-Malassis de agosto-septiembre 1862 (Correspondance II, p. 257).
} 
de esa tercera edición, que debía llevar un dossier final con los textos del juicio, ${ }^{14}$ corre en paralelo con el proyecto del Spleen de Paris y refuerza la hipótesis de un lazo entre ambos textos mediado por la condena penal. Los cien poemas en prosa vendrían a reparar el corte, operado por la censura, de los cien poemas de la primera edición del 57.

La sombra del juicio se proyecta de este modo sobre los dos centros neurálgicos de la obra baudelairiana; la sombra del juicio también sitúa la carta prefacio a Houssaye, de 1862, en un esquema de resistencia a la censura padecida cinco años antes. Una resistencia que se da desde la forma, y que busca explorar modelos discursivos que no dependan de una estructura fija o de un soporte material vulnerable ante la cesura. ¿Cómo inventar una estructura lo suficientemente maleable para resistir la intervención externa -política, mediática, judicial- sin verse deformada, tal como había sucedido con el esquema de 1857? ¿Cómo lograr que el cuerpo textual cumpla a la vez con requisitos de flexibilidad y de solidez?

El motivo de la serpiente infinitamente divisible es la respuesta que Baudelaire ofrece, con tono zumbón, en su entrega del 26 de agosto de 1862 para el diario La Presse $e^{15}$. Reproducimos el primer párrafo de la carta-dedicatoria a

14 Corr II, p. 522, Carta del 9 de agosto de 1865 a Julien Lemer. "Fleurs du mal, augmentées de plusieurs pièces, — et de plusieurs articles et lettres, relatifs à la première et seconde édition. (Théophile Gautier, Sainte-Beuve, Edouard Thierry (Moniteur), Asselineau, d'Aurévilly, Custine, Deschamps, etc.) »

15 “À Arsène Houssaye" aparece el 26 de agosto de 1862 en La Presse, diario que Houssaye dirigía. Reproducimos el texto, en traducción de Santiago Venturini, en el archivo anexo. 
Arsène Houssaye, en la versión al castellano que Santiago Venturini prepara para la colección "Colihue Clásica":

Mi querido amigo, le envío una obrita de la que nadie puede decir, sin injusticia, que no tiene ni cola ni cabeza, porque todo en ella, al contrario, es a la vez cola y cabeza (...). Considere, se lo ruego, las admirables comodidades que tal combinación nos ofrece a todos, a usted, a mí y al lector. Podemos cortar donde queramos: yo mi ensoñación, usted el manuscrito, el lector su lectura, ya que no someto la voluntad reacia de éste al hilo interminable de una intriga excesiva. Quite una vértebra, y los dos pedazos de esta tortuosa fantasía volverán a unirse fácilmente. Córtela en numerosos fragmentos, y verá que cada uno puede existir por separado. Con la esperanza de que algunos de estos pedazos tengan vida suficiente como para agradarle y divertirle, me atrevo a dedicarle la serpiente entera (Traducción en anexo).

No es esta la primera aparición de la serpiente asociada a la realidad material del libro en la textualidad baudelairiana. Un antecedente sobre el que deseamos detenernos y que Michel Butor analizó con brillo en Histoire extraordinaire. Essai sur un rêve de Baudelaire (1961) se da en el sueño que el poeta narra, en carta del 13 de marzo de 1856, a su amigo Charles Asselineau. En ese texto relata Baudelaire un sueño que sucede sólo tres días después de la publicación y distribución, el 10 de marzo, de su primer libro real -no plaqueta, no revista, no diario-: las Histoires extraordinaires de Poe. Aunque se trate de una traducción, el libro funciona simbólicamente como propio, primero porque, a diferencia de su traductor Poe es más o menos un desconocido en el ambiente; segundo, porque 
Baudelaire publica en los diarios varios adelantos del prefacio, "Edgar Poe, sa vie et ses œuvres", que los colegas elogian como si fuera un texto autónomo (Nadar, por caso, escribe en el Journal amusant que "el prefacio es tan curioso e interesante como el libro”). Tal como analiza Juan Zapata (2017), en la campaña por conseguir editor para sus traducciones de Poe, Baudelaire moviliza "estrategias editoriales", "cálculos institucionales" y un dispositivo de representaciones ligadas al malditismo que legitiman su propio posicionamiento en el campo. El manuscrito de la carta confirma la vivencia de la traducción como texto propio: señala Pichois una tachadura significativa donde el autor borra "mon livre" y lo remplaza por "le livre" (Corr I, p. 885, nota a). Digamos por último que para esa misma época Baudelaire está considerando firmar con Michel Lévy un contrato para su propio libro de poemas (que finalmente editará Poulet-Malassis), por lo que en el sueño se superponen distintas dimensiones autorales ligadas, concreta o abstractamente, con el libro como acontecimiento.

Baudelaire redacta la carta con el sueño "aún en caliente" en la madrugada del 13. También es de madrugada en la escena onírica ("las dos o tres de la mañana") cuando el poeta se dirige hacia un burdel que pertenece -dirá más adelante- al diario Le Siècle, con "un libro [suyo] que acababa de aparecer" para regalárselo a la dueña del lugar. En cuanto llega, sin embargo, se siente desnudo: le falta un zapato, tiene los pies mojados y sucios, la bragueta abierta y el sexo expuesto. Pero ese escenario rápidamente se evapora y tras la exhibición violenta, obscena- el sueño ya "no trata sobre el libro". 
"Il n'est plus question du livre", aunque sí persisten en el sueño los rasgos que constituyen espacios tópicos, estereotipados, que representan el conflicto de la publicación en el siglo XIX: la exhibición circense, el anfiteatro médico, el prostíbulo. Antes de retomar el hilo de la serpiente y del sueño, quisiéramos analizar brevemente estos espacios alegóricos en torno a la publicación que aparecen tanto en el sueño como en "Mademoiselle Bistouri” y que representan, a nuestro entender, el conflicto entre autonomía y mercado que está en el centro del proceso penal.

\section{Alegorías de la publicación}

Una estructura de sensibilidad, un sentir común que recorre el siglo y al que Baudelaire no es del todo ajeno, recela en la publicación el riesgo de un malentendido. El libro sugiere una exhibición indebida porque expone ante el ojo público una obra creada en soledad o en intimidad amorosa con la Musa, la Poesía o la Imaginación, figuras alegóricas a menudo representadas en ilustraciones y paratextos. Esa representación, en el libro impreso, de una escena privada de escritura que la edición pública del libro viene justamente a perturbar, condensa las tensiones que provoca la instancia editorial en tiempos de la profesionalización del escritor. Al problema, simbólico, de la exhibición se suma otro: el de la venta del libro, que mancilla una intimidad cuyo valor residía justamente en carecer de precio; de allí la esperable analogía con la prostitución. "Esa prostitución del pensamiento que llamamos 
publicación", ${ }^{16}$ sentencia por caso el joven Honoré de Balzac en un texto de 1829, el "Avertissement du Gars". Y acota:

El autor de la obra que publicamos acepta, pues, alegremente, entrar en la compañía de ilustres bailarines de cuerda que intentan divertir al público con sus trucos a cambio de dinero. Aquellas imágenes que no debían salir de su alma, los cuadros esbozados, que se borraban apenas se los dibujaba y que velozmente pasaban por su pensamiento más secreto, signados por la gracia de las auroras, esos cuadros describió, exponiéndolos a la mirada de todos, y vio cómo perdían su flor virginal. Su imaginación, nos dice, la verdadera y fiel compañera de los hombres de voluntad potente, esa esposa de quien solo deberíamos recibir misteriosamente las caricias, hará públicas sus efusiones (...) Basta con un solo testigo o con miles, la vergüenza o el éxito consumarán el mismo crimen en ese comercio del espíritu (...) ¡Cuánto más encantadora y bella, la casta musa cuyos pies delicados no salieron del círculo de los corazones! (Balzac 1829 [1966]: 21]. ${ }^{17}$

\section{Prostitución y circo: Balzac combina en su burlesca alegoría} dos modos de la exhibición tarifada. En el siglo del negocio del espectáculo público, de los fenómenos de feria y de las maisons

\footnotetext{
${ }^{16}$ «Cette prostitution de la pensée qu’on nomme: la publication. »

17 «L'auteur de l'ouvrage que nous publions a donc consenti de bonne grâce à entrer dans la compagnie des illustres danseurs de corde qui, dit-il, s'efforcent, pour de l'argent, d'amuser le public par leurs tours. Les images qui ne devaient pas sortir de son âme, les tableaux au trait, aussitôt effacés que dessinés qui passaient rapidement dans sa pensée secrète empreints de la grâce des aurores, il les a décrits, et en les exposant aux regards de tous, il leur verra perdre (leur fleur virginale). Cette imagination, nous écrit-il, la vraie et fidèle compagne des hommes puissants de volonté, cette épouse dont nous devrions ne recevoir que mystérieusement les caresses, va rendre ses épanchements publics (...) Un seul connaisseur ou des milliers, la honte ou le succès vont consommer également un crime (...) Combien est plus ravissante et plus belle, la muse chaste dont les pieds délicats ne sont pas sortis de l'enceinte des cœurs!»
} 
closes que exhiben mujeres, las comparaciones del autor que publica libros con el acróbata que baila sobre una cuerda floja o con la prostituta, cargan la instancia de publicación con una conflictividad nueva, de orden moral, donde la circulación pública de los textos editados implica algún tipo de traición o sometimiento. En su ya clásico Portrait de l'artiste en saltimbanque (1970), Jean Starobinski leyó agudamente cómo la identificación del artista con el payaso, en el XIX, es una "forma indirecta y paródica de plantear la cuestión del arte" (p.8) y una "autocrítica dirigida contra la propia vocación estética" (p. 9). En este mismo sentido interpretaba ya Starobinski, en un trabajo de 1967, las figuras del payaso y del saltimbanqui en Baudelaire: el poeta, narrador-testigo de "una agonía, en el sentido fuerte del término" (1967, p. 412) (piénsese en "Une mort héroïque" o en "Le Vieux saltimbanque"), es aquel que presencia la entrega sacrificial del saltimbanqui al público, y en ese espectáculo proyecta su propia conciencia de la muerte y de la impotencia del arte (1967, p. 412). Implícita en la lectura de Starobinski está la traición espuria de aquello que debía permanecer en la sombra: el dolor, que se vuelve insumo para la risa, provoca "el nacimiento del payaso trágico", por usar la fórmula del crítico ginebrino. Es en "La Muse vénale" donde payaso, prostituta y poeta comparten el estigma común de la exhibición pública ${ }^{18}$ : "Es preciso que, para ganarte el pan de cada noche (...) muestres [étales], saltimbanqui en ayunas, tus encantos / y tu sonrisa bañada en lágrimas que no se ven" (1857 [2006],

${ }^{18}$ Ver al respecto el artículo de Cristian Molina en este mismo número. 
p.33). ${ }^{19}$ Étaler: 'exhibir para vender', define el Littré. El articulador que une las tres figuras es la exhibición a cambio de dinero. Si se decodifica la alegoría del escritor-histrión en términos de producción material, la exposición pública que redunda en espectáculo arancelado para el payaso y en comercio sexual para la prostituta, culmina, en el caso del escritor, en la necesaria venta de su libro, aquel "comercio del espíritu" del que hablaba Balzac.

En esta tensión se configura el íntimo drama de la exhibición del sujeto a través del libro. Escribe Flaubert, en carta del 11 de enero 1859, a Ernest Feydeau:

Un libro es algo esencialmente orgánico, es parte de nosotros mismos. Nos arrancamos del vientre un poco de tripas que les servimos a los burgueses. Las gotas de nuestra sangre pueden verse en los caracteres de nuestra escritura. Pero en cuanto se edita, buenas noches. ¡Le pertenece a cualquiera! ¡La multitud nos pisa el cuerpo! ¡Es el grado más alto y más vil de la prostitución! Aunque todo el mundo coincide en que [publicar] es algo muy bello, y que prestar el culo por diez francos es una infamia. ¡Así sea! (Corr III, p. 5) ${ }^{20}$

\footnotetext{
${ }^{19}$ «Il te faut (...) saltimbanque à jeun, étaler tes appas /et ton rire trempé de pleurs qu'on ne voit pas, / Pour faire épanouir la rate du vulgaire » (OC I, p. 15)

20 «Un livre est une chose essentiellement organique, cela fait partie de nous-mêmes. Nous nous sommes arrachés du ventre un peu de tripes, que nous servons aux bourgeois. Les gouttes de notre cœur peuvent se voir dans les caractères de notre écriture. Mais une fois imprimé, bonsoir. Cela appar-tient à tout le monde ! La foule nous passe sur le corps! C'est de la prostitution au plus haut degré et de la plus vile ! Mais il est reçu que c'est très beau, et que prêter son cul pour dix francs est une infamie. Ainsi soit-il!» (Corr III, p. 5)
} 
La cita prolonga la consubstanciación orgánica entre cuerpo y escritura, de antiguo linaje romántico; ${ }^{21}$ Flaubert aún lee la tinta y la sangre como flujos que traducen emociones, desde una suerte de teoría de los humores. Sin embargo, la tinta de la pluma amiga es también la de la imprenta pública: el sostén de la materialidad del texto, de su edición y circulación anónima. En este sentido, la amalgama entre sangre y tinta configura un complejo entramado de representaciones que alegoriza negativamente los conflictos entre dinero y proyecto estético, en los tiempos de la circulación a nueva escala del texto impreso. Para Flaubert, esa circulación implica violencia y vejación, destrucción del cuerpo autoral (“iLa multitud nos pisotea el cuerpo!”), en una vivencia traumática que no se corresponde del todo, como veremos, con la de Baudelaire.

En la muy conocida caricatura de Achille Lemot, ${ }^{22}$ sangre y tinta reaparecen unidas en la pluma escalpelo que Flaubert hinca en el cuerpo de Emma, para mostrar aquello que usualmente permanece oculto. La cirugía exhibe los órganos internos; la novela, la psique del personaje:

\footnotetext{
21 "Les gouttes de notre cœur peuvent se voir dans les caractères de notre écriture": en un giro estilístico que le es propio, el autor del Dictionnaire des idées reçues actualiza, enrareciéndolo, un lugar común inscripto en la lengua: "se faire un sang d'encre": 'angustiarse'. La expresión es de uso común a partir del siglo XVIII.

22 La Parodie, 5-12 de diciembre de 1869. En línea: http://flaubert.univrouen.fr/iconographie/lemot.php
} 


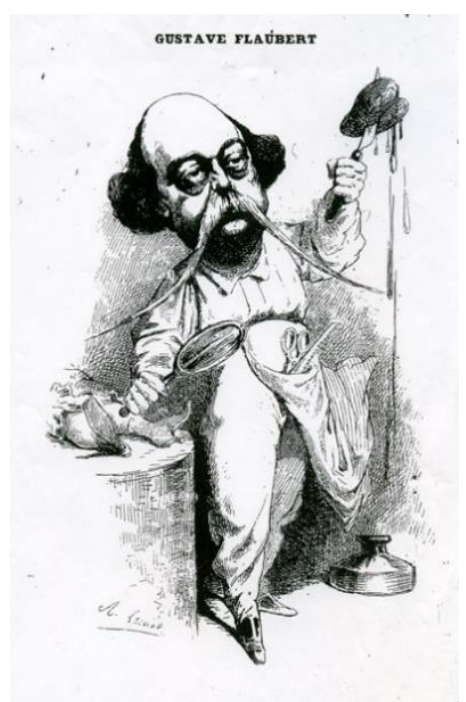

Achille Lemot, “Gustave Flaubert”, La Parodie, 5-12 de diciembre de 1869

Nótese que el hombrecito Flaubert blandiendo un escalpelo, con el cadáver de Emma sobre una camilla, a sus espaldas, y un tintero gigante en el piso, alude doblemente al prestigioso oficio paterno y a la exhibición rentada, por medio de la publicación, del métier literario. Recuérdese también el carácter espectacular de la disección humana en los anfiteatros o "teatros anatómicos" del siglo XVIII. Esta práctica se prolonga en el XIX, como lo analiza Jerôme Thélot (2014, p.221-222), en la exhibición y reificación del interior del cuerpo expuesto a "la curiosidad del público" en esquemas, estampas y lecciones de anatomía que objetivan de forma sistemática, a la luz de un saber positivo y de una estética naturalista, aquellos órganos, humores y flujos que hasta entonces no eran vistos. La cirugía como exhibición del interior del cuerpo, la publicación como exhibición del alma: los espacios tópicos se 
solapan para representar el problema no resuelto de la circulación pública -necesaria, deseada, resistida- del texto estético.

Teniendo en cuenta estos escenarios alegóricos de la publicación, el sueño del 13 de marzo adquiere una nueva densidad simbólica y espacial. El prostíbulo por el que el poeta deambula es comparado con "una especie de museo médico". En las "vastas galerías" hay fotos y cuadros de fetos de "pájaros coloridos con plumajes muy brillantes, en los que el ojo está vivo" (eran los hijos de las prostitutas) y en medio de estas piezas de exhibición descubre un ser igualmente vivo, expuesto como monstruo de feria:

(...) se trata de un monstruo que nació en la casa y que está eternamente parado sobre un pedestal. Entonces es parte del museo, aunque es un ser vivo. No es feo. Su semblante es incluso gracioso, muy bronceado, de color oriental. Hay en él mucho rosa y mucho verde. Está agachado, aunque en una posición extravagante y contorsionada. Además tiene algo negruzco que da varias vueltas alrededor de sus miembros, como una serpiente gruesa. Le pregunto qué es y me responde que es un apéndice monstruoso que le sale de la cabeza, algo elástico como caucho, y tan largo, tan largo que si se lo envolviese alrededor de la cabeza como una cola de caballo sería demasiado pesada y absolutamente imposible de llevar, y por eso está obligado a enroscárselo en torno a los miembros, lo que produce el más bello de los efectos. Converso largamente con él. Me participa de sus fastidios y tristezas. Hace ya muchos años que se ve obligado a permanecer en esa sala, sobre ese pedestal, debido a la curiosidad del público. Pero su principal fastidio llega a la hora de la cena. Como es un ser vivo, está obligado a cenar con las muchachas de la casa - a caminar tambaleándose con su apéndice de caucho hasta el 
comedor- y allí debe mantenerlo enrollado alrededor de sí, o acomodarlo sobre una silla como un manojo de cuerdas, porque si lo deja arrastrar por el suelo le tiraría la cabeza hacia atrás. Encima está obligado, siendo pequeño y gordito, a comer junto a una chica alta y esbelta. Por lo demás, me da todas estas explicaciones sin amargura. No me atrevo a tocarlo, pero me intereso por él (Corr I, p. 338341; mi traducción).

La narración del sueño se corta ahí porque -anota Baudelaire en la carta- "en ese momento" su mujer hace ruido moviendo un mueble y él se despierta, aquejado por un punzante dolor en la espalda, las caderas, las piernas. Entonces le escribe a Asselineau: "Presumo que estaba durmiendo en la posición enroscada del monstruo" ("la position contournée du monstre"). Aunque Baudelaire decline toda voluntad de interpretación del sueño ("un lenguaje jeroglífico del que no tengo la clave" dice al principio), la identificación final con el monstruo es explícita y la misiva, que se abrió con la mención del libro recién publicado que quería llevarle a la dueña del burdel, se cierra con el monstruo expuesto "a la curiosidad del público."

Aparecen, decíamos, los núcleos semánticos de la tópica negativa en torno a la publicación (exhibición circense, prostitución, medicalización burlesca) aunque desplazados y ambiguos, porque en el sueño de Baudelaire la exhibición es obscena, en algún punto gozosa y no carente de comicidad: las tonalidades rosa y verde del monstruo sobre el pedestal con su priápica addenda, el "bello efecto" que produce su figura, el paso de comedia entre el monstruo "pequeño y gordito" y la 
prostituta "alta y esbelta", el erotismo doméstico en la mesa del comedor, los "fastidios y tristezas" de la vida cotidiana. El relato que Baudelaire vuelca en la carta configura de esta manera una microsecuencia entre cómica y grotesca que debilita la fuerza condenatoria de la red circo-prostituciónpublicación. Pero esa red sigue siendo el espacio alegórico al que el poeta recurre, como sus pares, para significar su propia ambivalencia ante la mirada externa: tanto el libro como la serpiente que lleva sobre la cabeza exponen al sujeto a "la curiosidad del público" y en ambos casos esa exposición implica goce, comicidad y angustia.

En la carta dedicatoria a Arsène Houssaye, la serpienteapéndice del sueño metaforiza la estructura del Spleen de París. Con una diferencia importante: si en el sueño la serpiente condenaba al monstruo a la exhibición circense, en la guía de lectura propuesta por Baudelaire para sus poemas en prosa, seis años más tarde, con el juicio de por medio, ese mismo motivo se vuelve fabuloso antídoto en contra de eventuales ataques externos, pues el poemario ya no ofrece una estructura compacta que se desarma al perder alguna de sus partes. El "sans queue ni tête" o "à la fois tête et queue" del Spleen serpentino se opone en este sentido al anterior "perfecto conjunto" (énfasis de Baudelaire -OC I, p. 194) que era la edición de 1857, o al "comienzo y fin" que su autor reclama, en carta a Vigny, para la edición de 1861 de las Flores (Corr II, p. 196). Como la serpiente se regenera siempre -más allá de cualquier consideración material, periodística o judicial- el texto se vuelve inasible, no justiciable, o por decirlo con Baudelaire: no hay "injusticia" posible en términos de coerción 
legal o de censura. La "serpiente entera", en continua palingenesia, deshace y obtura el recorte bajo todas sus formas: la desatención caprichosa del lector que lee a saltos, la fragmentación de los diarios, la censura y sus mutilaciones. Publicar esto en un periódico (recordemos que la carta a Houssaye aparece el 26 de agosto de 1862 en La Presse) revela todo el esplendor de la ironía baudelairiana.

En el sueño, o más bien en la carta que es su registro escrito, el movimiento que iba del poeta y su libro al monstruo y su serpiente-falo traducía la consubstanciación entre sujeto y libro. Leída desde esa relación, la condena materializa temiblemente fantasías pasadas: de forma autorreflexiva e irónica, el monstruo sobre el pedestal anuncia el apéndice monstruoso que nace con la publicación y sus posteriores avatares editoriales; también sugiere hasta dónde, y con qué violencia, la censura será vivida como una mutilación de la propia carne, que "Mademoiselle Bistouri" intentará revertir.

\section{El poeta, cirujano y verdugo}

En "Mademoiselle Bistouri"'3 (OC I, p. 353-6), de 1867, reaparecen las tijeras que diez años antes recortaron la obra. Nuestra idea es que de forma desorbitada y bufona Baudelaire reactualiza en la loca figura de la Bistouri las conminaciones de

\footnotetext{
23 Aunque la publicación de "Mademoiselle Bistouri" es anunciada en los números del 14, 21 y 28 de septiembre de 1867 de La Revue nationale et étrangère, el texto recién aparece en la edición póstuma de 1869 (Murphy 2003, p.483). El texto, en traducción de Santiago Venturini, se reproduce en el archivo anexo.
}

$N^{\circ}$ 8. Primer Semestre de 2018 
la ley y sus guardianes del mismo modo en que, en el tiempo del juicio, había acudido al imaginario quirúrgico para significar los efectos impensados de la censura sobre el cuerpo homogéneo del texto. ${ }^{24}$ Mademoiselle Bistouri como encarnación, como deriva bufa de los riesgos de la publicación: se trata, en nuestra lectura, de una presentación hiriente y grotesca de los gajes del oficio, de una transfiguración burlesca de los padecimientos legales sucedidos diez años antes.

La presencia directa del sujeto histórico Baudelaire en "Mademoiselle Bistouri" ha sido discutida; Steve Murphy (2003, p. 515-518) subraya la necesaria distinción metodológica entre narrador, poeta y autor empírico. Sin embargo, no puede dejar de observarse -como lo hace el propio Murphy- que varios rasgos del narrador coinciden con el perfil biográfico del autor: conocedor, como Baudelaire, del Quai Voltaire (el domicilio de la juventud), lector de los "mismos antiguos poetas franceses" (Régnier), fisiólogo, flâneur. Más aún, el ethos de ese narrador en sus distintas modulaciones -el esteta que enuncia juicios, el conocedor de las anomalías de la ciudad, la voz desesperada de la invocación final- evoca el ethos de la obra crítica y poética previa; tal como lo ha identificado la crítica $^{25}$, las numerosas redes intertextuales que recorren el texto remiten a la propia obra baudelairiana, en particular a $L a$

\footnotetext{
${ }^{24}$ Poco después de la sentencia, en un episodio conocido, Poulet-Malassis arrancará las páginas con los poemas condenados y venderá el libro a precio de mercado negro. Escribe entonces Baudelaire, en carta del 9 de octubre de 1857: "Si vous pouviez comprendre quel tort vous vous êtes fait avec votre ridicule opération chirurgicale?" (Corr I, p. 429).

${ }^{25}$ Ver al respecto Bonnefis, p. 135-136; Murphy p. 519-520; Cornille p. 102; Marder p.15 y p.18.
} 
Fanfarlo y a las "Viudas". Estas marcas, que bordean la autoficción, autorizan una lectura de "Mademoiselle Bistouri" desde la experiencia de publicación, juicio y censura de Les Fleurs du mal. Se trataría, en este sentido, del examen velado, distanciado por la ironía y la teatralización, de una experiencia dolorosa: un examen no distinto, quizá, del proceso de transfiguración burlesca que seis años más tarde, en 1873, se dará en la "Vierge folle" de Rimbaud, en Une Saison en enfer.

La problemática de la publicación y la censura aparece, por lo demás, en la evocación de aquellos escenarios alegóricos que recién analizábamos en el sueño unido a la publicación de la traducción de Poe: prostitución, circo, exhibición médica. Estos escenarios aparecen indirectamente, sin fijarse del todo, en las secuencias donde la Bistouri asume los roles de la prostituta, la animadora de feria, la cirujana. La mujer se presenta alternativamente como prostituta que merodea y atrae desconocidos, pero que en vez de recibir dinero, regala calor, vino y cigarros; como propietaria de una colección de imágenes que exhibe ante el público anónimo venido de la calle, al modo de los animadores de feria; o como aspirante a cirujana que busca recrear, a través de "la colección de retratos de los médicos ilustres de ese tiempo", un espacio colegiado de observadores e intérpretes. Cada rol implica algún tipo de exposición pública y en cierta medida alude a los escenarios tópicos de esa exhibición indebida que el siglo asocia con la publicación y que el propio Baudelaire evocaba en el sueño donde su libro, apenas editado, se perdía en ese espacio metamórfico que oscilaba entre el burdel, el museo médico y la feria. 
A su vez se dibuja en filigrana el guion del juicio. En el teatro de sombras chinas que la Bistouri construye en su cuarto, a partir de fotos y litografías, aparecen deformados los agentes de la persecución legal: periodistas, censores y jueces. Significativamente vuelven a enunciarse, en este texto de 1867, frases de la correspondencia escrita en la época del juicio. Dos días antes de la audiencia, en la conocida carta del 18 de agosto de 1857 a Madame Sabatier donde Baudelaire describía a su acusador ("Pinard: redoutable"), apuntaba el poeta: "He visto a mis jueces este último jueves. No diré que no son bellos: son abominablemente feos, y su alma debe parecerse a su rostro" ${ }^{26}$ " (Corr I, p. 422). «Este es Z. El que decía en sus clases, hablando de X.: "¡Este monstruo lleva en el rostro la negrura de su alma!"» ${ }^{27}$ (OC I, p. 354), le hace decir, en estilo directo, Mlle. Bistouri a uno de los retratos ${ }^{28}$. Jean-Louis Cornille (2010, p. 103), que también relaciona ambos fragmentos, señala además el paralelismo sonoro entre Mademoiselle Bistouri y Madame Bovary: si la Bistouri es vestigio del proceso penal, comparte elenco con la protagonista de la novela de Flaubert, perseguida unos meses antes en esa misma Sexta cámara del Tribunal correccional de París por el mismo abogado, Ernest Pinard.

\footnotetext{
26 «J'ai vu mes juges, jeudi dernier. Je ne dirai pas qu'ils ne sont pas beaux, ils sont abominablement laids, et leur âme doit ressembler à leur visage.»

${ }^{27}$ «Voilà Z. Celui qui disait à son cours, en parlant de X.: « Ce monstre qui porte sur son visage la noirceur de son âme!»

28 El nombre provendría de una crónica parisina, "La mère Bistouri", firmada por Adrien Marx, publicada el 30 de enero de 1866 en L'Époque. Ver al respecto Murphy 2003, pp. 484-492.
} 
La analogía entre el acto de supresión de los seis poemas y la loca actividad de la Bistouri es de por sí imaginable: la aspirante a cirujana que junta "fajos de papel" y se marea con la fantasía del corte quirúrgico puede ser leída como una versión fuera de eje del censor. ¿ $\mathrm{O}$ acaso la navaja, las tijeras, cualquier "lame" o filo, no son el principal atributo de Anastasie, la célebre caricatura de André Gill (1874) sobre la censura, y de todas las figuras alegóricas que le precedieron Dame Censure, Dame Séraphine, Dame aux ciseaux (Delporte, 1997, pp. 88-95) - surgidas al calor de las leyes de censura del impreso público de 1820-1821? Sin embargo, en un gesto que altera el orden de la coacción, en el poema en prosa Mlle. Bistouri inviste de poder al narrador al conferirle el uso de los instrumentos de corte y sutura: "Recuerdo que era usted quien lo asistía en las operaciones graves. ¡Este es un hombre al que le gusta cortar, rebanar y cercenar! Era usted el que le alcanzaba los instrumentos, los hilos y las esponjas ${ }^{29}$." No es ya el censor quien maneja las tijeras, sino el narrador que adquiere ese poder gracias a la intervención de la Bistouri. "Flaubert tenía de su lado a la Emperatriz. Me falta una mujer" (Corr I, p.522) [Flaubert avait pour lui l'Impératrice. Il me manque une femme]. Dos días antes de la audiencia del juicio, en la ya mencionada carta del 18 de agosto de 1857, Baudelaire le pedía ayuda a la Presidenta Sabatier con la esperanza de una intervención providencial que repitiera la hazaña de Flaubert, cinco meses antes. El pedido tiene la ironía dramática de las grandes farsas, ahora que esa mujer es la Bistouri; mediante la mágica y

${ }^{29}$ «En voilà un homme qui aime couper, tailler et rogner ! C'était vous qui lui tendiez les instruments, les fils et les éponges. » 
burlesca fuerza performativa de su teatro privado, la "bufona creatura" le devuelve el control, la capacidad de cortar, desplazar, pegar; en suma: la capacidad de editar. De forma significativa, en el diálogo previo el narrador ya había asumido el poder de la escisión, el desmembramiento y el corte: “¿Cirujano entonces? — ¡No! ¡No! ¡A menos que sea para cortarte la cabeza ${ }^{30 !}$ ! La extraña figura metamórfica que en "Mademoiselle Bistouri" va del cirujano al verdugo adquiere una nueva luz si se la sitúa en las inmediaciones del juicio ${ }^{31}$. En Charles Baudelaire. Sa vie, son cuvre (1869: 127), Asselineau ponía en boca de Pinard, durante el juicio, esta frase: “¡Dios mío! No pido la cabeza de M. Baudelaire! Sólo pido una advertencia..."32

El recorte judicial de la censura como intervención quirúrgica, la condena penal como decapitación del condenado: Baudelaire instala el registro discursivo del juicio en el doble plano de la violencia política revolucionaria y de la intervención del orden burgués en el régimen estético. Esa articulación, recurrente en el último Baudelaire, lee en la Revolución uno de los motivos de la mediocridad actual: origen oculto de la actual burguesía triunfante, la Revolución, junto a Dame Guillotine, le habría conferido el poder a los mediocres - periodistas, jueces, censores- que hoy, bajo el orden del Segundo Imperio, atacan su creación artística. La misma idea aparece en otros textos con la fuerza de la

\footnotetext{
30 «Chirurgien, alors? — Non! non ! à moins que ce ne soit pour te couper la tête !»

31 Ver al respecto el análisis que propusimos en "Las Flores del mal de Charles Baudelaire, una historia material".

32 «Mon Dieu! je ne demande pas la tête de M. Baudelaire! je demande un avertissement seulement...»
} 
evidencia. "Charpentier, que corrige a sus autores gracias a la igualdad asignada a todos los hombres por los inmortales principios del 89" (OC I, p. 685): tal es la descripción que da Baudelaire en Mon cour mis à nu de Gervais Charpentier, inventor del libro de bolsillo, que modificaba sin consultarlo la puntuación de sus poemas en La Revue Nationale. ${ }^{33}$ Los “inmortales principios del 89" reaparecen en otro poema en prosa, "Le miroir" [E espejo] (OC I, p. 344), donde un hombre horrible se mira la espantosa cara "con disgusto"; hacerlo es aquí también otro derecho adquirido "d'après les immortels principes de 89", que en este caso legitiman la existencia misma de su fealdad ${ }^{34}$. El sarcasmo vuelve una y otra vez para postular en la burguesía triunfante y sus patéticas ambiciones el verdadero legado de 1789, lo que confirmaría la lectura de Benjamin, que veía en Baudelaire "un agente secreto -el agente de la secreta insatisfacción de su clase respecto de su propio señorío" ([1938] 1974, p.1161). Para el poeta, la violencia que el nuevo régimen burgués ejerce sobre su texto remite a la violencia fundante de esa misma soberanía, surgida del hecho revolucionario. La analogía del corte -como cirugía, como decapitación- metaforiza la violencia de Estado y une el levantamiento revolucionario con la actual tiranía de la manada

\footnotetext{
33 Ver al respecto la carta que Baudelaire envía a Charpentier el 20 de junio de 1863: "Monsieur, acabo de leer los dos recortes ("Les Tentations" y "Dorothée") insertos en la Revue Nationale. Y me encuentro con cambios extraordinarios hechos después de mi autorización de publicación. Por este motivo, Monsieur, le huyo a los diarios y a las revistas. Yo le había dicho: suprima todo el conjunto si una coma le disgusta en el conjunto, pero no suprima la coma; ella tiene su razón de ser. He pasado mi vida entera aprendiendo a construir frases y le digo, sin miedo de caer en el ridículo, que lo que yo entrego a la imprenta está terminado de forma perfecta. (Corr II, p. 307).
}

34 Ver al respecto el análisis que ofrece Compagnon (2014, pp. 13-40) sobre estas ambivalencias ideológicas del antimoderno. 
democrática, que promueve la censura. "A los burgueses; ustedes son la mayoría -número e inteligencia-; luego son la fuerza, que es la justicia ${ }^{35}$ ", escribe Baudelaire en la irónica dedicatoria del Salón de 1846 (OC II, p. 415). Desde esta grilla de lectura pueden entenderse quizá mejor las figuras complementarias del verdugo y del cirujano, del corte y la decapitación, que el poeta convoca con fiereza tras el juicio y que funcionan como "répondants allégoriques" de la figura del poeta, según la expresión de Starobinski: intermediarios alegóricos del escritor, que aquí se enfrentan al conflicto político. Escriben los Goncourt ([1857] 2008, p. 211) en un entrada del Journal de octubre 1857:

Hoy, Baudelaire cena cerca nuestro. No lleva corbata, tiene el cuello a la vista, la cabeza rapada, un verdadero atuendo de guillotinado. En el fondo, un rebuscamiento voluntario, con las manitos lavadas, lustradas, cuidadas como manos de mujer - pero también la cara de un maníaco, la voz cortante como el acero y una dicción que apunta a la precisión con ornatos de un Saint-Just y la consigue. Obstinadamente, con furia áspera, se defiende de haber ultrajado a la moral en sus versos. ${ }^{36}$

\footnotetext{
35 « Vous êtes la majorité, -nombre et intelligence ; - donc vous êtes la force, - qui est la justice. »

36 Ver al respecto Cámpora 2019. «Baudelaire soupe aujourd'hui à côté de nous. Il est sans cravate, le col nu, la tête rasée, en vraie toilette de guillotiné. Au fond, une recherche voulue, de petites mains lavées, écurées, soignées comme des mains de femme - et avec cela une tête de maniaque, une voix coupante comme une voix d'acier, et une élocution visant à la précision ornée d'un Saint-Just et l'attrapant. Il se défend obstinément, avec une certaine colère rêche, d'avoir outragé les mœurs dans ses vers. » (Edmond y Jules de Goncourt, 2008, p. 211).
} 
La proliferación de imágenes médicas en "Mademoiselle Bistouri" a su vez dialoga con los fundamentos ideológicos y con las formaciones discursivas a los que Pinard recurre en su alegato en contra de Las Flores del mal. Debido a la asociación tópica entre vicio, enfermedad y pecado y a la tipificación del delito por el que se persigue a Baudelaire -ultraje a la moral pública- la acusación de Pinard durante el juicio ${ }^{37}$ se construye argumentalmente en torno a la tradición discursiva que une delito y enfermedad, en el entendimiento de una correlación entre el mal físico y el mal moral que afectaría, texto mediante, a la comunidad. La enorme ironía de este giro argumental de la acusación reside en su cercanía ideológica con las propias concepciones maistrianas que nutren la idea del mal en Baudelaire, y que también leen en la enfermedad material una "manifestación física del Mal en la carne", tal como lo analizó Patrick Labarthe (2015: 339). La idea de una insalubridad de los poemas, de un veneno que ataca a la sociedad y corrompe a las nuevas masas ${ }^{38}$ de lectores, aparece en distintos momentos de la intervención del Abogado Imperial, que designa al poemario como "fiebre malsana", falso "antídoto", "veneno"

\footnotetext{
${ }^{37} \mathrm{O}$ más bien, para ser precisos, el texto publicado en 1885 que hoy llega a nuestras manos como registro de ese alegato. A diferencia de Flaubert que pagó un estenógrafo, Baudelaire no previó el registro de su juicio. El expediente se perdió en el incendio del Palacio de Justicia durante la Comuna, en mayo de 1871 (Guyaux 2006, p. 1034). El único registro del alegato de Pinard es el que fue publicado en la Revue des grands procès contemporains (OC I, p. 1206-1209), en 1885, en una versión probablemente digitada por el propio abogado imperial preocupado, con razón, por su fama póstuma.

38 Pregunta retóricamente Pinard: "Esos muchos lectores para los que usted escribe, pues la tirada de su libro es de varios miles de ejemplares y el precio de venta es muy bajo- esos numerosos lectores, de cualquier clase, de cualquier edad o condición, ¿̇abrán acaso tomar el antídoto que con tanta ligereza usted les propone?”
}

N 8. Primer Semestre de 2018 
que "sube a la cabeza, marea los nervios, produce malestar, vértigo, e incluso puede matar ${ }^{39}$ ", (OC I, p. 1206-1208). Diez años más tarde aparecerán como respuesta a ese mal los simulacros de médicos en "Mademoiselle Bistouri", remedios burlescos, atravesados de irrealidad, que rebaten la enfermedad moral del juicio: los retratos de "doctores célebres" colgados en la pared ${ }^{40}$; los manojos de fotos de "médicos ilustres" a quienes la Bistouri hace hablar; las visitas de la mujer a jóvenes internos, la fantasía de verlos aparecer en su cuarto con implementos manchados de sangre; la asimilación del narrador con una ayudante quirúrgico que maneja "instrumentos, hilos y esponjas" y ayuda al médico mayor que tanto "ama cortar, rebanar y cercenar".

Enfermedad, delito y poesía ya estaban presentes en el artículo del 5 de julio de 1857 firmado por Gustavo Bourdin en Le Figaro. En un texto que Baudelaire define como una "delación" (OC I, p.1177) y que sin lugar a dudas puso en marcha el proceso legal ${ }^{41}$, Bourdin asigna negativamente las Flores al espacio clínico: "Este libro es un hospital abierto a todas las demencias del espíritu ${ }^{42 "}$ (Guyaux 2007, p. 160). Una semana más tarde, Jean Habans prolonga en el mismo diario la

\footnotetext{
39 «De bonne foi, croyez-vous qu'on puisse tout dire, tout peindre, tout mettre à nu, pourvu qu'on parle ensuite du dégoût né de la débauche et qu'on décrive les maladies qui la punissent ? Croit-on que certaines fleurs au parfum vertigineux soient bonnes à respirer ? Le poison qu'elles apportent n'éloigne pas d'elles; il monte à la tête, il grise les nerfs, il donne le trouble, le vertige, et il peut tuer aussi. »

40 « deux ou trois portraits de docteurs célèbres étaient suspendus au mur »

${ }^{41}$ Ver al respecto Pichois 1973, p. 1177; Leclerc 1991, p. 70.

${ }^{42}$ « Ce livre est un hôpital ouvert à toutes les démences de l'esprit Ce livre est un hôpital ouvert à toutes les démences de l'esprit. »
} 
metáfora del espíritu como carne enferma al condenar los "horrores de matadero exhibidos fríamente, esos abismos de inmundicia hurgados con ambas manos y con la camisa arremangada" (Guyaux, 2007, p. 163). ${ }^{43}$ Delaciones: el paralelismo es posible entre los periodistas que en 1857 señalaban al Ministerio público las ofensas "a la moral pública y a las buenas costumbres" en los libros recién editados y el médico del hospital que, según la Bistouri, denunciaba "rebeldes" al gobierno en el "tiempo de las revueltas" ${ }^{44 ", ~ e n ~ l a s ~}$ jornadas de junio 1848.

La conexión metafórica entre ambas delaciones, la real y la ficticia, la del periodista y la del médico, superpone escenarios, representaciones, discursos. Hacia el final de la crónica, la entrevista del narrador con Mademoiselle Bistouri se vuelve interrogatorio («suivant à mon tour, moi aussi, mon idée fixe », «Moi, m'obstinant, je repris ») que la mujer contesta con evasivas:

Yo, obstinadamente, insistí: “¿Puedes recordar la época y el momento en que nació esta pasión tan particular?". Me costó hacerme comprender; al final lo logré. Pero entonces me respondió con una apariencia muy triste y, hasta donde puedo recordar, desviando la mirada: "No sé, no me acuerdo (Traducción en anexo). ${ }^{45}$

43 « ces horreurs de charnier étalées à froid, ces abîmes d'immondices fouillés à deux mains et les manches retroussées »

44 «Tiens, voilà K., celui qui dénonçait au gouvernement les insurgés qu’il soignait à son hôpital. C'était le temps des émeutes. »

45 “"Moi, m’obstinant, je repris: «Peux-tu te souvenir de l'époque et de l'occasion où est née en toi cette passion si particulière ? " Difficilement je me fis comprendre ; enfin j’y parvins. Mais alors elle me répondit d'un air très triste, et même, autant que je peux me souvenir, en détournant les yeux: "Je ne sais pas... je ne me souviens pas.»"

$N^{\circ} 8$. Primer Semestre de 2018 
Una escena similar se deduce del alegato del Abogado Imperial:

Sin embargo, después de haber escuchado las explicaciones contradictorias de la audiencia, ¿se sienten lo suficientemente seguros como para condenar en base al segundo cargo [la ofensa a la moral religiosa]? Ustedes sabrán evaluar si Baudelaire, ese espíritu atormentado, que quiso más bien hacer algo extraño, no blasfemo, tuvo conciencia de esa ofensa (OC I, p. 1207). ${ }^{46}$ [énfasis mío]

El enunciador de esas "explicaciones contradictorias" e insuficientes es el acusado Charles Baudelaire, que Pinard caracteriza de modo paternalista y condescendiente, en un tono semejante al que el narrador emplea para referirse a la "bufonesca creatura" "de ojos muy abiertos" en el poema en prosa.

\section{Sans injustice}

"Mademoiselle Bistouri" retoma, deformándolo, el amplio abanico de representaciones que construyeron la persecución mediática y legal, así como las contraimágenes que Baudelaire opuso al ataque: insalubridad de los poemas, veneno que ataca al cuerpo social, lenguaje enfermo y nocivo, cirugía, corte, filo, guillotina. Al mismo tiempo, el poema en prosa opera una inversión en el manejo legal de la violencia y del castigo, ya que

\footnotetext{
46 «Mais, après les explications contradictoires de l'audience, avez-vous la certitude nécessaire pour condamner sur le second chef ? Vous apprécierez si Baudelaire, cet esprit tourmenté, qui a voulu faire de l'étrange plutôt que du blasphème, a eu conscience de cette offense-là. »
} 
el narrador-poeta asume, Bistouri mediante, el doble poder de advertencia y mutilación que antes poseía Pinard, su acusador. Todo se mantiene sin embargo en la indeterminación de la farsa: las identidades vacilan y el "enigma inesperado" que es la mujer permanece irresuelto.

Más profundamente, el texto es una interrogación sobre la justicia y sobre sus condiciones de posibilidad: ¿quién puede ser juez y de qué? ¿Existe una justicia superior, que entiende los "motivos" y las "causas"? La invocación final es de ambigua incerteza, entre la plegaria deseante y el soliloquio que lleva las marcas de la ironía más desesperada:

¡Cuántas rarezas se encuentra uno en una gran ciudad, cuando sabe pasear y mirar! La vida rebosa de monstruos inocentes. -Señor, ¡Dios mío! tú, el Creador, tú, el Maestro; tú que hiciste la Ley y la Libertad; Tú, el soberano que deja hacer, tú, el juez que perdona; tú que estás lleno de motivos y de causas, y que tal vez pusiste en mi espíritu el gusto del horror para convertir mi corazón, como la curación al filo de una navaja; Señor, jten piedad, ten piedad de los locos y de las locas! ¡Oh, Creador! ¿Pueden acaso existir monstruos para Él, el único que sabe por qué existen, cómo se bicieron y cómo podrían no baberse becho? (Traducción en anexo)

Ley, Libertad, soberano que deja hacer, juez que perdona, Tú que estás lleno de motivos y de causas: a primera vista, el campo conceptual es cristiano, jansenista; proyecta angustiosamente la posibilidad de comprensión y justicia en un orden trascendente, que ha de revelar lo inextricable del orden humano, justificándolo, reparándolo, aun cuando ahora sólo haya el silencio de Dios. Desde un punto de vista formal, la 
invocación se inscribe en la tradición litúrgica del Kirie Elison ("Señor, ten piedad") donde se ruega la intercesión divina en un movimiento de entrega y reconocimiento de la propia impotencia e incomprensión. En "Mademoiselle Bistouri", la exclamación final sin embargo relativiza la posibilidad de esa intercesión, ya que el "Señor", el "Creador" no consuela ni comparte su saber con aquellos que permanecen rodeados por locos, locas y monstruos. Renan, unos años más tarde, escribirá en el mismo sentido:

Nunca estuvimos en esas situaciones trágicas donde Dios es de algún modo el necesario confidente que consuela. ¿Qué otra cosa, salvo levantar los ojos al cielo, pueden hacer una mujer pura acusada injustamente, una víctima inocente de un error judicial irreparable (...)? ¿Dónde buscar un testigo verdadero, si no es allá arriba? Pero lo increíble es que nunca nada indica que nuestra queja haya tocado algo. Cuando Nemrod lanzaba sus flechas contra el cielo, le volvían ensangrentadas. Nosotros, nosotros no obtenemos respuesta alguna. ¡Oh Dios, a quien adoramos a pesar nuestro, a quien rogamos veinte veces por día sin saberlo, realmente eres un Dios oculto! (1892: 13) ${ }^{47}$

En su lectura del Kirie Eleison que cierra el poema en prosa, Patrick Labarthe ve en este acobijarse en el mantra rítmico de la letanía un resguardo formal ante la dureza de la contingencia

\footnotetext{
${ }^{47}$ « Nous n'avons jamais été dans une de ces situations tragiques où Dieu est en quelque sorte le confident et le consolateur nécessaire. Que voulez-vous que fassent, si ce n'est lever les yeux au ciel, une femme pure accusée injustement, un innocent victime d'une erreur judiciaire irréparable (...)? Où chercher le témoin vrai, si ce n'est en haut? Mais ce qu'il y a d'inouï, c'est que jamais rien n'indique que notre protestation ait touché quelque chose. Quand Nemrod lançait ses flèches contre le ciel, elles lui revenaient ensanglantées. Nous autres, nous n'obtenons aucune réponse. O Dieu, que nous adorons malgré nous, que nous prions vingt fois par jour sans le savoir, tu es vraiment un Dieu caché !»
} 
y del mal: "inscribir lo negativo (lo caótico, lo monstruoso, lo irreparable) en una forma con el rigor suficiente como para designar, entre precariedad existencial y exactitud metafórica, la lejana unidad perdida" (2015, pp. 677-8).

Pensamos, en cambio, que esa invocación final participa del secreto, ambiguo propósito compensatorio del texto. Si seguimos el análisis de Georges Blin en "Baudelaire et le recours à la sorcellerie" (1948, pp. 84-90), hay en Baudelaire una apuesta por la fuerza performativa, energética, cabalística de la oración, más allá incluso de la fe en la existencia de Dios: una oración que opera "por la virtud intrínseca de la invocación, independientemente del destinatario" (p. 86). "La Letra tiene una eficacia propia" (p. 87) y la energía volcada en la oración "vuelve sobre sí misma, retroactivamente, para 'recargar' la voluntad" (p. 90). Discurren aquí, subterráneamente, los principios del cientificismo romántico: magnetismo orgánico, galvanismo, fluidos eléctricos. Baudelaire asocia la oración con una "higiene" que convoca fuerza vital y formas nuevas de la voluntad: ya no se busca, en definitiva, "gobernar lo divino, sino movilizar y reagrupar -en una suerte de tensión eficiente- una potencialidad que es de origen humano" (p. 89). A diferencia de Renan, que no creía en la eficacia ni inmanente ni trascendente de la oración, apuesta Baudelaire por la "fuerza material" de la plegaria, unida a una "dinámica moral" cuyas líneas de fuerza expone en Mon cour mis à nu:

La fuerza del amuleto demostrada por la filosofía. Les suelos agrietados, los talismanes, los recuerdos de cada uno. 
Tratado de dinámica moral. Sobre la virtud de los sacramentos.

Ya en mi infancia, tendencia al misticismo. Mis conversaciones con Dios.

Sobre la Obsesión, sobre la Posesión, sobre la Oración y sobre la Fe.

Dinámica moral de Jesús.

Renan encuentra ridículo que Jesús crea en la fuerza todopoderosa, incluso material, de la Oración y la Fe.

Los sacramentos son los medios de esta dinámica. ${ }^{48}$

Si se la piensa como una puesta en acto de esa energía humana que recurre a las fórmulas, las liturgias, el recogimiento de la plegaria, la invocación final intenta restablecer un orden, reparar, curar, en un acto de autoconciencia y recuperación: "Tú (...) que tal vez pusiste en mi espíritu el gusto del horror para convertir mi corazón, como la curación al filo de una navaja”. Más o menos para la misma época, en la serie de escritos íntimos que Claude Pichois titula "Hygiène ${ }^{49 "}$ ", el poeta se proponía actos y ejercicios voluntaristas en contra del dolor psíquico, la enfermedad y la acedia: "Higiene, conducta, método. A partir de ahora, juro ante mí mismo seguir las siguientes reglas como

${ }^{48} \mathrm{La}$ force de l'amulette démontrée par la philosophie. Les sols percés, les talismans, les souvenirs de chacun. / Traité de dynamique morale. De la vertu des sacrements. / Dès mon enfance, tendance à la mysticité. Mes conversations avec Dieu. / De l'Obsession, de la Possession, de la Prière et de la Foi. / Dynamique morale de Jésus. / Renan trouve ridicule que Jésus croie à la toute-puissance, même matérielle, de la Prière et de la Foi. / Les sacrements sont des moyens de cette dynamique. (OC I, p. 706).

49 «Dieu, réservoir de toute force et de toute justice », «me fier à Dieu, c'est-à-dire à la Justice même » 
reglas eternas de mi vida" (OC I, p. 673). ${ }^{50}$ Allí definía Baudelaire a Dios como "reservorio de toda fuerza y de toda justicia" y pedía "confiarse a Dios, es decir, a la Justicia misma". ${ }^{51}$

En "Mademoiselle Bistouri", la invocación al "Maestro", al "juez que perdona" e hizo "la Ley y la Libertad" reconfigura las coordenadas del juicio de 1857 al proyectarlas -alegóricas, desviadas- en un plano divino que ambiguamente remite a la propia fuerza regeneradora del individuo: a su "dinámica moral", a la "todopoderosa" fuerza material de la oración. Según nuestra lectura, la comedia de la Bistouri y los médicos vendría a obturar burlescamente el cargo de enfermedad social, de veneno para las masas endilgado a Las Flores por su acusador, y a hacerle eco a esa otra "comedia" que fue el juicio penal tal como lo describió el poeta, cinco días después de la condena, en carta a Gustave Flaubert (Corr I, p. 424). Podría incluso pensarse, en este sentido, en una ambigua dramatización litúrgica, donde la "bufonesca creatura", "enigma inesperado", funciona al modo de los chivos expiatorios del Antiguo Testamento (nuevamente de Maistre) que atraen sobre sí la negatividad de una situación específica: el rito teatral que convoca vestigios discursivos, imágenes y procedimientos condensaría la absurdez del proceso penal, absorbería su daño a fin de ofrecerle al perseguido "la curación

\footnotetext{
50 «Hygiène, conduite, méthode. Je me jure à moi-même de prendre désormais pour règles éternelles de ma vie »

51 «Faire tous les matins ma prière à Dieu, réservoir de toute force et de toute justice, à mon père, à Mariette et à Poe, comme intercesseurs (...) me fier à Dieu, c'est-à-dire à la Justice même, pour la réussite de mes projets »
} 
al filo de una navaja". "Mademoiselle Bistouri" como curación irónica del daño del juicio, de la injusticia de los jueces, del orden jurídico positivo y de sus farsas: tal es el rango del experimento que quisiéramos leer en la escritura de este poema en prosa.

\section{Referencias Bibliográficas}

Asselineau, C. (1869). Charles Baudelaire, sa vie et son œeuvre. París : Alphonse Lemerre.

Balzac, H. (1966). Avertissement du Gars. La Comédie Humaine (t. I). Roland Chollet (ed.). Paris : Cercle du Bibliophile.

Baudelaire, C. (1869). Petits Poëmes en prose. Les Paradis artificiels, Paris, Michel Lévy Frères.

---. (1975). Correspondance 1832-1860. Claude Pichois y Jean Ziegler (eds.). Paris: Gallimard, «Bibliothèque de la Pléiade ».

---. (1976). Correspondance 1860-1866. Claude Pichois y Jean Ziegler (eds.). Paris : Gallimard.

---. (1975). Euvres Complètes (2 vols.) Claude Pichois (ed.). Paris : Gallimard, « Bibliothèque de la Pléiade ».

---. (2006). Las Flores del mal. Trad. de Américo Cristófalo. Buenos Aires: Colihue, Colección "Colihue Clásica”.

---. (2009). Mi corazón al desnudo. Trad. Jorge Segovia. Madrid: Maldoror Ediciones.

Benjamin, W. ([1938] 1974). Gesammelte Schriften. Frankfurt am Main: Suhrkamp. 
Bonnefis, P. (1987). Mesures de l'ombre. Lille: Presses Universitaires de Lille.

Cámpora, M. (2019). "Las Flores del Mal de Charles Baudelaire, una historia material”, Prismas. Revista de Historia Intelectual, en prensa.

Compagnon, A. (2014). Baudelaire l'irréductible. Paris : Flammarion.

Cornille, J-L. (2010). "Chirurgie et Esthétique Baudelairienne ». Romance Studies, 28 (2), pp. 96-105.

Butor, M. (1961). Histoire extraordinaire. Essai sur un rêve de Baudelaire. Paris : Gallimard.

Delporte, C. (1997). "'Anastasie' : l'imaginaire de la censure dans le dessin satirique (XIXe-XXe siècles). Pascal Ory, (Dir.). La censure en France à l'ère démocratique (1848-...). Editions Complexe : Bruxelles, pp. 89-102.

Dulaure, J-A. (1805). Des Divinités génératrices, ou du Culte du phallus chez les anciens et les modernes; Des cultes des dieux de Lampsaque, de Pan, de Vénus, etc. Paris, Dentu.

Foerster, M. (2018). The Politics of Love: Queer Heterosexuality in Nineteenth-Century French Literature. Durham, NH: University of New Hampshire Press.

Goncourt, Edmond y Jules de (2008). Journal des Goncourt : 1858-1860. Jean-Louis Cabanès (ed). París: Honoré Champion.

Guyaux, A. (2007). Baudelaire. Un demi-siècle de lecture des Fleurs du mal, 1855-1905. París : Presses de l'Université de Paris-Sorbonne.

Hannoosh, M. (2011). "Reading the Trial of the Fleurs du Mal". The Modern Language Review, 106 (2), pp. 374-387.

Labarthe, P. (2015). Baudelaire et la tradition de l'allégorie. Genève: Droz. 
Laplanche, J. y Pontalis, J-B. (1967). Diccionario de psicoanálisis, Fernando Gimeno Cervantes (trad.). Buenos Aires: Paidós [2004].

Leakey, F.W. (1996). "Les Fleurs du mal, a chronological view ». The Modern Language Review, 91, 3, pp. 78-581.

Leclerc, I. (1991). Crimes écrits. La Littérature en procès au XIXe siècle. Paris : Plon.

Linton, A. E. (2014). "Baudelaire's Monsters: 'Mademoiselle Bistouri' and Teratology”. Yale French Studies, 125/126, pp. 134-148.

Marder, E. (2017-2018). "Baudelaire's Feminine CounterSignature: "Mademoiselle Bistouri's Photographic Poetics ». Nineteenth-Century French Studies, 46 (1 \& 2), pp. 1-25.

Milner, M. (1967). Baudelaire: "enfer ou ciel, qu'importe !». París : Plon.

Mollier, J-Y. (1987). "Baudelaire et les frères Lévy: auteur et éditeur ». Études baudelairiennes, vol. XII, pp. 131-225.

Murphy, S. (2003). Logiques du dernier Baudelaire. París: Honoré Champion.

Murphy, S. (dir.). (2014). Lectures du Spleen de Paris. Rennes : Presses Universitaires de Rennes.

Renan, E. (1892). Feuilles détachées, faisant suite aux Souvenirs d'enfance et de jeunesse. Paris : Calmann Lévy.

Ruff, M. (1955). L'esprit du mal et l'esthétique baudelairienne. París : Armand Colin.

Vaillant, A. (2009). " Baudelaire, artiste moderne de la 'poésiejournal'», Études Littéraires, 40, 3, pp. 43-60.

Starobinski, J. (1967). "Sur quelques répondants allégoriques du poète ». Revue d'Histoire littéraire de la France, 67, 2, pp. 402-412. 
---. (1970). Portrait de l'artiste en saltimbanque. Paris : André Skira éd.

Tabarovsky, D. (ed.) (2011). El origen del narrador. Actas completas de los juicios a Flaubert y Baudelaire. Buenos Aires: Mardulce.

Vaillant, A. (2007). Baudelaire, poète comique. Rennes : Presses Universitaires de Rennes.

Zanelli Quarantini, F. (2008). " Et ces maudites Fleurs du mal qu'il faut recommencer! », Francofonia, 54, pp. 175-185.

Zapata, J. (2017). «Baudelaire: traductor-auctoritas». Literatura: teoría, historia, crítica, 19, 2, pp. 19-50. 


\section{ANEXO: TRADUCCIONES DE “À ARSÈNE HOUSSAYE" Y "MADEMOISELLE BISTOURI", POR SANTIAGO VENTURINI ${ }^{52}$}

\section{PARA ARSÈNE HOUSSAYE}

Mi querido amigo, le envío una obrita de la que no podría decirse, sin injusticia, que no tiene ni pies ni cabeza, porque al contrario, todo en ella es, a la vez, pies y cabeza, alternativa y recíprocamente. Considere, se lo ruego, las admirables comodidades que tal combinación nos ofrece a todos, a usted, a mí y al lector. Podemos cortar donde queramos, yo mi ensoñación, usted el manuscrito, el lector su lectura, ya que no dejo colgando la voluntad reacia de éste del hilo interminable de una intriga superflua. Quite una vértebra, y los dos pedazos de esta tortuosa fantasía volverán a unirse fácilmente. Córtela en numerosos fragmentos, y verá que cada uno puede existir por separado. Con la esperanza de que algunos de estos pedazos estarán lo suficientemente vivos como para gustarle y divertirlo, me atrevo a dedicarle la serpiente entera.

Tengo una pequeña confesión que hacerle. Fue al hojear, al menos veinte veces, el famoso Gaspar de la Noche de Aloysius Bertrand (un libro conocido por usted, por mí y por algunos amigos, ¿no tiene todo el derecho de ser llamado famoso?) que me vino la idea intentar algo análogo, y aplicar a la descripción de la vida moderna, o mejor dicho de una vida moderna y más abstracta, el procedimiento que él aplicó a la pintura de la vida antigua, tan extrañamente pintoresca.

¿Quién de nosotros no ha soñado, en sus días de ambición, con el milagro de una prosa poética, musical sin ritmo ni rima, tan liviana y contrastante como para adaptarse a los

52 Agradezco a Santiago Venturini este avance de su traducción de Le Spleen de Paris. Petits Poèmes en Prose (Colihue, Col. "Colihue Clásica”, en preparación). 
movimientos líricos del alma, a las ondulaciones del ensueño, a los sobresaltos de la conciencia?

Es sobre todo de la frecuentación de las ciudades enormes, del entrecruzamiento de sus innumerables relaciones, que nace este ideal obsesivo. Usted mismo, mi querido amigo, ¿no intentó traducir en una canción el grito estridente del Vidriero, y expresar en una prosa lírica todas las desoladoras sugestiones que ese grito envía hasta las buhardillas, a través de las brumas más altas de la calle?

Pero, a decir verdad, temo que mi celo no me haya traído suerte. Apenas comencé el trabajo me di cuenta de que no sólo estaba bastante lejos de mi misterioso y brillante modelo, sino que incluso hacía algo (si es que eso puede llamarse algo) singularmente diferente, accidente del que cualquier otro se enorgullecería sin duda, pero que no puede más que humillar profundamente un espíritu como el mío, que ve como el más alto honor del poeta realizar exactamente lo que había proyectado.

Suyo, muy afectuosamente,

$$
\text { C.B. }
$$

$*$

\section{XLVII}

\section{SEÑORITA BISTURÍ}

Cuando llegaba a las afueras del suburbio, bajo los resplandores del gas, sentí que un brazo se deslizaba suavemente bajo el mío, y escuché que una voz me dijo al oído: “¿Usted es médico, señor?”.

La observé; era una muchacha alta, robusta, con los ojos muy abiertos, apenas maquillada, sus cabellos flotaban en el viento con las cintas de su gorro. 
“-No, no soy médico. Déjeme pasar. -jSí! Usted es médico, se nota. Venga a mi casa. Estará muy contento conmigo, jvamos! -Iré a verla, tal vez, pero más tarde, después del médico, iqué diablos! -jAh, ah! - dijo ella, todavía colgada de mi brazo y estalló en risas- usted es un médico bromista, conocí a varios así. Vamos".

Amo apasionadamente el misterio, porque siempre tengo la esperanza de desenredarlo. Por eso me dejé arrastrar por esa compañera, o más bien por ese enigma inesperado.

Omito la descripción de la pocilga; es posible encontrarla en muchos viejos poetas franceses muy conocidos. Sólo un detalle no percibido por Régnier: dos o tres retratos de doctores célebres colgaban de las paredes.

¡Cómo fui mimado! Buen fuego, vino caliente, cigarrillos; al ofrecerme estas buenas cosas y encendiéndome ella misma un cigarrillo, la bufonesca criatura me decía: "Siéntase como en su casa, amigo mío, póngase cómodo. Esto le recordará el hospital y los buenos tiempos de la juventud. - ¿Y eso? ¿De dónde sacó esas canas? Antes, hace no mucho tiempo, usted no era así, cuando era interno de L... Recuerdo que era usted quien lo asistía en las operaciones graves. ¡Este es un hombre al que le gusta cortar, rebanar y cercenar! Era usted el que le alcanzaba los instrumentos, los hilos y las esponjas. - Y cuando la operación estaba lista, él decía con orgullo, mirando su reloj: "¡Cinco minutos, señores!" - ¡Oh! Yo voy por todas partes. Conozco bien a estos señores".

Algunos segundos después, tuteándome, retomaba su cantinela y me decía: "Eres médico, ¿no es cierto, gatito mío?"

Este incomprensible estribillo me hizo levantarme de un salto. “¡No!”, grité furioso.

-¿Cirujano, entonces?

-¡No y no! ¡A menos que sea para cortarte la cabeza! S... s... c... de s... m...!

-Espera, continuó ella, vas a ver". 
Y sacó de un armario un fajo de papeles, que no era otra cosa que la colección de los retratos de los médicos ilustres de ese tiempo, litografiados por Maurin, que se exhibieron durante varios años en el muelle Voltaire.

"Mira, ¿Reconoces a este?".

- ¡Sí! Es X. El nombre aparece debajo, por cierto, pero no lo conozco personalmente.

-¡Lo sabía! ¡Mira! Este es Z., el que en sus clases decía, al hablar de X.: " ¡Este monstruo que lleva en su rostro la negrura de su alma!" ¡Y todo porque el otro no compartía su misma opinión sobre un mismo asunto! ¡Cómo nos reíamos de eso en la Escuela, en aquel tiempo! ¿Te acuerdas? -Mira, este es K., el que denunciaba al gobierno a los insurgentes que cuidaba en su hospital. Era el tiempo de las revueltas. ¿Cómo es posible que un hombre tan bello tenga tan poco corazón? -Y aquí está W., un famoso médico inglés, lo atrapé cuando vino a París. Parece una señorita, ¿no es cierto?”.

Y como toqué un paquete atado con cintas, que estaba sobre la mesita: "Espera un poco -me dijo-; esos son los internos y en este paquete están los externos".

Y desplegó en abanico una masa de imágenes fotográficas que representaban fisonomías mucho más jóvenes.

"Cuándo nos volvamos a ver me darás tu retrato, ¿no es cierto, querido?

-Pero, le dije, siguiendo yo también con mi idea fija -¿por qué te parezco un médico?

-¡Es que eres tan amable y bueno con las mujeres!

- Extraña lógica! -me dije a mí mismo.

-¡Oh! Casi nunca me equivoco, conocí a bastantes médicos.

Quiero tanto a esos señores que, aunque no esté enferma, voy a veces a verlos, nada más que para verlos. Hay algunos que me dicen con frialdad: “¡Usted no está nada enferma!" Pero hay otros que me entienden, porque les hago caritas.

$-¿ Y$ cuándo no te entienden? 
- ¡Vaya! Como los molesté inútilmente, dejo diez francos sobre la chimenea. -jSon tan buenos y tan dulces, esos hombres! En la Piedad descubrí a un joven interno, bello como un ángel, iy tan educado! ¡Y cómo trabaja, el pobre muchacho! Sus camaradas me dijeron que no tenía un peso, porque sus padres son pobres y no pueden enviarle nada. Eso me dio confianza. Después de todo, soy una mujer bastante bella, aunque ya no $\tan$ joven. Le dije: "Ven a verme, ven a verme seguido. Y no te preocupes conmigo, yo no necesito dinero". Pero entenderás que se lo di a entender de mil maneras, no se lo dije así crudamente. ¡Tenía tanto miedo de humillar a ese niño querido!

- ¡Y bien! ¿Creerás que tengo un deseo extraño que no me atrevo a confesarle? - ¡Me gustaría que viniera a verme con su maletín y su delantal, incluso manchado con un poco de sangre!".

Dijo esto con un aire tan cándido, como un hombre sensible le diría a una actriz que admira: "Quiero verla vestida con el traje que llevaba para ese famoso papel que creó una vez".

Yo, obstinadamente, insistí: "¿Puedes recordar la época y el momento en que nació esta pasión tan particular?”.

Me costó hacerme comprender; al final lo logré. Pero entonces me respondió con una apariencia muy triste y, hasta donde puedo recordar, desviando la mirada: "No sé, no me acuerdo". ¡Cuántas rarezas se encuentra uno en una gran ciudad, cuando sabe pasear y mirar! La vida rebosa de monstruos inocentes. Señor, ¡Dios mío! tú, el Creador, tú, el Maestro; tú que hiciste la Ley y la Libertad; Tú, el soberano que deja hacer, tú, el juez que perdona; tú que estás lleno de motivos y de causas, y que tal vez pusiste en mi espíritu el gusto del horror para convertir mi corazón, como la curación al filo de una navaja; Señor, ;ten piedad, ten piedad de los locos y de las locas! ¡Oh, Creador! ¿Pueden acaso existir monstruos para Él, el único que sabe por 
qué existen, cómo se hicieron y cómo podrían no haberse hecho? 